\title{
Supporting Holistic Student Development Through Online Community Building
}

\author{
Katrina Borowiec \\ Deoksoon Kim \\ Lizhou (Jo) Wang \\ Julie Kim \\ Stanton Wortham \\ Boston College, USA
}

\begin{abstract}
Faculty members abruptly transitioned to online course delivery during the COVID-19 public health crisis. Unfortunately, the isolation of learning online had the potential to damage students' well-being during an already stressful pandemic. Furthermore, many faculty members had little experience with online modes of instruction and few effective strategies for building community online. This exploratory sequential mixed methods study uses data from 37 individual interviews with faculty across diverse disciplines, course evaluations from 13 of the 37 interview participants, and survey data from 347 faculty to answer the following research question: How did faculty foster a sense of community online to support students' holistic well-being during the COVID pandemic? What strategies can faculty use to create community and foster well-being in online courses? Results show that successful strategies centered around intentional and purposeful course design, establishing clear expectations for faculty and students, and fostering supportive and trustworthy online learning environments.
\end{abstract}

Keywords: online community, teaching presence, social presence, holistic education, student well-being, COVID-19 pandemic

Borowiec, K., Kim, D., Wang, L., Kim, J., \& Wortham, S., (2021). Supporting holistic student development through online community building. Online Learning, 25(4), 145-155.

DOI: $10.24059 /$ olj.v25i4.2882 
Online higher education enrollment has grown substantially. The proportion of undergraduates in the United States enrolled in at least one online course increased from $8 \%$ in 2000 to 34\% in 2018 (Radford, 2011; U.S. Department of Education, 2019). Online education was essential to educational continuity during the COVID-19 pandemic, when nearly all instruction was delivered online. However, only $44 \%$ of instructors had online teaching experience as of fall 2018 (Inside Higher Ed \& Gallop, 2018), suggesting that most instructors taught online for the first time during the pandemic, with minimal preparation. In response to the COVID-19 crisis, most faculty did "emergency remote teaching" (Hodges et al., 2020).

Many students also studied online for the first time in Spring 2020, not by choice. Only $6.8 \%$ of students entering college in fall 2019 reported that there was a "very good chance" of taking an online course (Stolzenberg et al., 2020, p. 47). College students and their families recognize the critical role of campus environments in shaping students' success (Astin, 1999; Museus, 2014; Pascarella \& Terenzini, 2005; Tinto, 1998). When designed effectively, campus environments support students' intellectual growth, while often supporting holistic development along moral, ethical, spiritual, social, and emotional dimensions (Grant, 2012; Wortham et al., 2020).

Attention to students' holistic needs was particularly important during the COVID pandemic, given students' additional challenges. In 2020, 58\% of college students experienced insecurity in their basic needs, including homelessness, housing insecurity, and/or food insecurity (Goldrick-Rab et al., 2020). Many students also experienced worsening mental health (Healthy Minds Network \& American College Health Association, 2020), technological barriers (Hart et al., 2021; Quezada et al., 2020), and concerns about the pandemic's impact on job prospects (Zhai \& $\mathrm{Du}, 2020$ ).

Supportive online classrooms can help meet students' holistic needs through an intentional focus on community building. Sense of community involves the feeling that one matters to a group of people; a feeling of social relatedness, support, and mutual contribution among individuals; and emotional connection (McMillan \& Chavis, 1986). In the context of online instruction, the "group" can be a classroom community, an instructor and students engaged in learning (Garrison et al., 1999; Rovai, 2000). Given the importance of interpersonal relationships, we agree with Love and Love (1995) who argue that separating students' intellectual needs from their social-emotional needs - and by extension, their spiritual, physical, and ethical needs (Kuh, 2018) —only serves to "break down" community (Love \& Love, 1995, p. 10). The strongest classroom communities will attend to students' holistic needs.

We recognize that prior to the COVID-19 pandemic many faculty attended to students' holistic needs when teaching online. However, the unique circumstances of the pandemic both heightened students' vulnerabilities and forced instructors into emergency remote/online teaching. Instructors have a pivotal role in building classroom community in online courses (Berry, 2017; Shea et al., 2005). Most faculty in our study had limited or no online teaching experience, which presents a unique opportunity to understand how faculty reacted to students' holistic needs when they were learning how to teach online during an immensely stressful global pandemic. This study asks: How did faculty foster a sense of community online to support students' holistic well-being during the COVID pandemic? What strategies can faculty use to create community and foster well-being in online courses? 
This study offers successful strategies for fostering a sense of community online. Even after the COVID-19 pandemic ends, online education is here to stay, and thus these strategies will remain useful.

\section{Literature Review}

We draw from research in three areas: students' holistic needs, sense of community online, and supporting students' holistic needs online during the COVID-19 pandemic. Below we highlight relevant literature from each area.

\section{Students' Holistic Needs}

Student development theories underscore the importance of identity formation during college (Baxter Magolda, 2020; Chickering \& Reisser, 1993; Patton et al., 2016). These theories envision identity as an integration along multiple dimensions. In this section, we use Chickering and Reisser's (1993) seven vectors of identity development and Baxter Magolda's (2020) selfauthorship theory to illustrate these theories.

Chickering and Reisser (1993) proposed seven vectors or facets of identity development. Four of these vectors are considered foundational to the others: (1) developing competence with respect to intellectual, intrapersonal, and physical skills; (2) managing and expressing emotions appropriately; (3) moving from autonomy and accepting one's independence, toward recognizing interconnectedness; and (4) developing mature interpersonal relationships (Chickering \& Reisser, 1993; Patton et al., 2016). These four vectors provide a foundation for the fifth vector, establishing identity, which involves self-acceptance across aspects of identity (e.g., gender, sexual orientation, cultural heritage). These five vectors allow for the sixth vector, developing purpose, which involves vocational goals and a sense of what is meaningful in life. The seventh vector is developing integrity, which means balancing personal values with social needs (Chickering \& Reisser, 1993; Patton et al., 2016).

Baxter Magolda's (2020) theory of self-authorship holds that individuals must answer three key questions related to epistemology, intrapersonal, and interpersonal dimensions. First, "How do I know?" is answered by developing one's internal beliefs. Second, "Who am I?" is answered by determining one's values and identity. Finally, "What kind of relationships do I want to construct with others?" is answered by learning how to build interpersonal relationships that support one's needs while respecting the others' needs (p. 74).

These two theories illustrate the multidimensional nature of student development. Supporting students' development requires a holistic approach (Kuh, 2018; Mayhew et al., 2016). In 2018, Kuh argued that, although holistic student development has been viewed as essential to a liberal arts education for decades, "the need has never been greater for educating the whole student by addressing one's intellectual, social, emotional, ethical, physical, and spiritual attributes" (p. 53). At the same time, he acknowledged that intellectual growth is often seen as more important than other aspects of development. Figure 1 displays the six dimensions of holistic development that were identified by Kuh, along with a brief definition of each area. 
Figure 1

Dimensions of Holistic Student Development (Kuh, 2018)

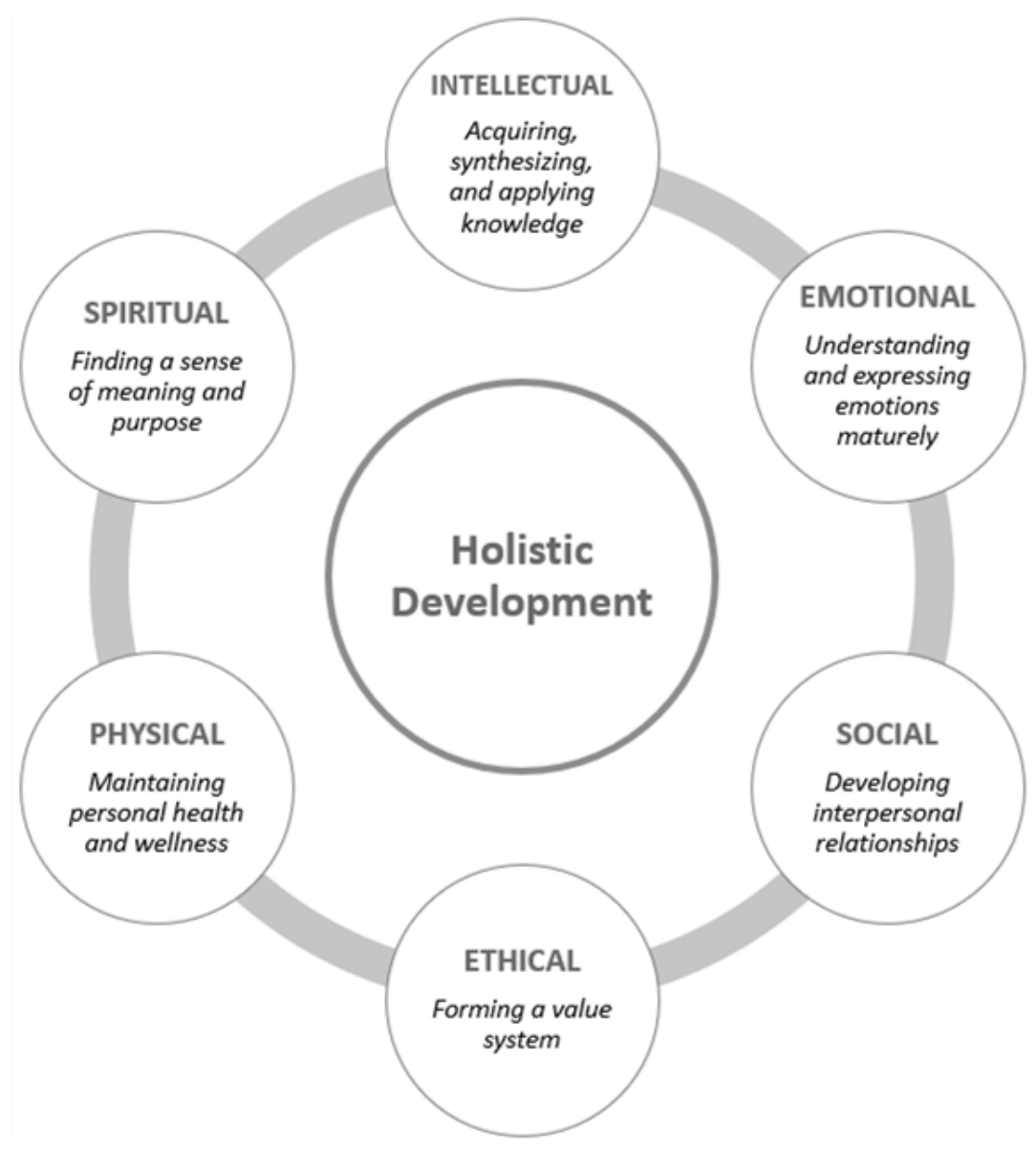

Sense of Community Online

Many students experience online courses as more isolating than in-person ones (McInnerney \& Roberts, 2004). Reading body language and social cues is challenging onlineespecially for asynchronous courses - potentially causing miscommunication (Rovai \& Jordan, 2004; Tryon \& Bishop, 2009). Educators need to enhance students' feelings of social connectedness online (Kauffman, 2015; Robinson \& Hullinger 2008), because community building is crucial to students' engagement in online courses (Castañeda \& Selwyn, 2018; Kilgour et al., 2019; Salmon, 2011).

The Community of Inquiry Framework (CoI) describes how instructors can foster a sense of community online (Garrison et al., 2010; Garrison \& Akyol, 2013). The framework has three interconnected components: teaching presence, social presence, and cognitive presence (Archibald, 2010; Berry, 2019; Shea \& Bidjerano, 2009). Teaching presence refers to the instructor's role in designing learning environments and selecting content that can enhance both social and cognitive presence (Garrison et al., 2010; Garrison \& Akyol, 2013). Social presence occurs when students are socially and emotionally engaged in the classroom and feel comfortable contributing. Cognitive presence involves students' engagement in critical reflection on their educational experiences (Garrison \& Akyol, 2013). 
Since teaching, social, and cognitive presences are interrelated, improvements in one impact the others. Effective instructional design, clear communication, clear course goals, productive time management, and comfort with online technologies are important factors in teaching presence (Oliphant \& Branch-Mueller, 2016; Shea et al., 2006; Song et al., 2004). One form of clear communication is direct one-on-one video or written communication, which reminds students that they are interacting with a "real" human being despite the physical distance (Berry, 2017; Lowenthal \& Dunlap, 2018). Moreover, through effective communication, instructors can improve social presence by becoming co-learners, showing empathy for students, reaching out to students who might need assistance, and addressing problems in classroom social dynamics (Ouyang \& Scharber, 2017; Whipp \& Lorentz, 2009). A well-designed course offers opportunities for students to collaborate through group assignments (Baker \& Edwards, 2011), enhancing social presence and communal bonds. In turn, when students feel connected, they may seek assistance from their classmates or the instructor, which will improve their learning and cognitive presence (Shea \& Bidjerano, 2009; Wei \& Chen, 2012).

\section{Supporting Students' Holistic Needs Online during the COVID-19 Pandemic}

Students encountered many challenges during the COVID-19 pandemic. About six out of ten college students experienced homelessness, housing insecurity, and/or food insecurity (Goldrick-Rab et al., 2020). Many students also suffered from mental health problems that were exacerbated by the pandemic (Healthy Minds Network \& American College Health Association, 2020). In spring $2020,45 \%$ of college students felt too physically or emotionally unwell to engage in their coursework (Means \& Neisler, 2021). More than 50\% of students reported that staying motivated, finding a quiet place to do schoolwork, and balancing coursework with family responsibilities was a problem in spring 2020 (Means \& Neisler, 2021). Internet access and hardware problems impeded students' engagement (Hart et al., 2021; Means \& Neisler, 2021; Quezada et al., 2020). International students also encountered challenges with time zone differences (Goin Kono \& Taylor, 2021). Pre-pandemic strategies for supporting students online and building communities were insufficient.

One-on-one interactions between faculty and students were critical to overcoming challenges and fostering holistic development (Goin Kono \& Taylor, 2021). Empathic interactions (Conklin \& Dikkers, 2021; Kim et al., 2021; Miller 2021), what Goin Kono and Taylor (2021) describe as an "ethos of care" (p. 156), were critical during the pandemic. In some cases, office hours allowed students to chat with instructors about their lives, rather than concentrating on course-related issues (Miller, 2021). Students appreciated instructors' attention to their needs during the pandemic (Conklin \& Dikkers, 2021; Means \& Neisler, 2021).

All this work highlights the multifaceted nature of college student development. A holistic approach is needed to adequately support students. And the COVID-19 pandemic pushed students' holistic needs to the forefront. Our study extends prior research by examining how online faculty fostered a sense of community online during the emergency transition to online learning during COVID-19. While most prior research has focused on students' perceptions of online community building, the current mixed methods study focuses on faculty members' perspectives. 


\section{Methodology}

This exploratory sequential mixed methods study explores how faculty can create communities online to support students' holistic development (Creswell \& Plano Clark, 2011; see Figure 2). The progression from qualitative to quantitative allowed us to ground our survey questions in the lived experiences of faculty. This is part of a larger study concerning faculty and student experiences teaching and learning online during the pandemic (see Kim et al., 2021). All participants were recruited from a private university in the northeast United States.

Figure 2

Exploratory sequential mixed methods design

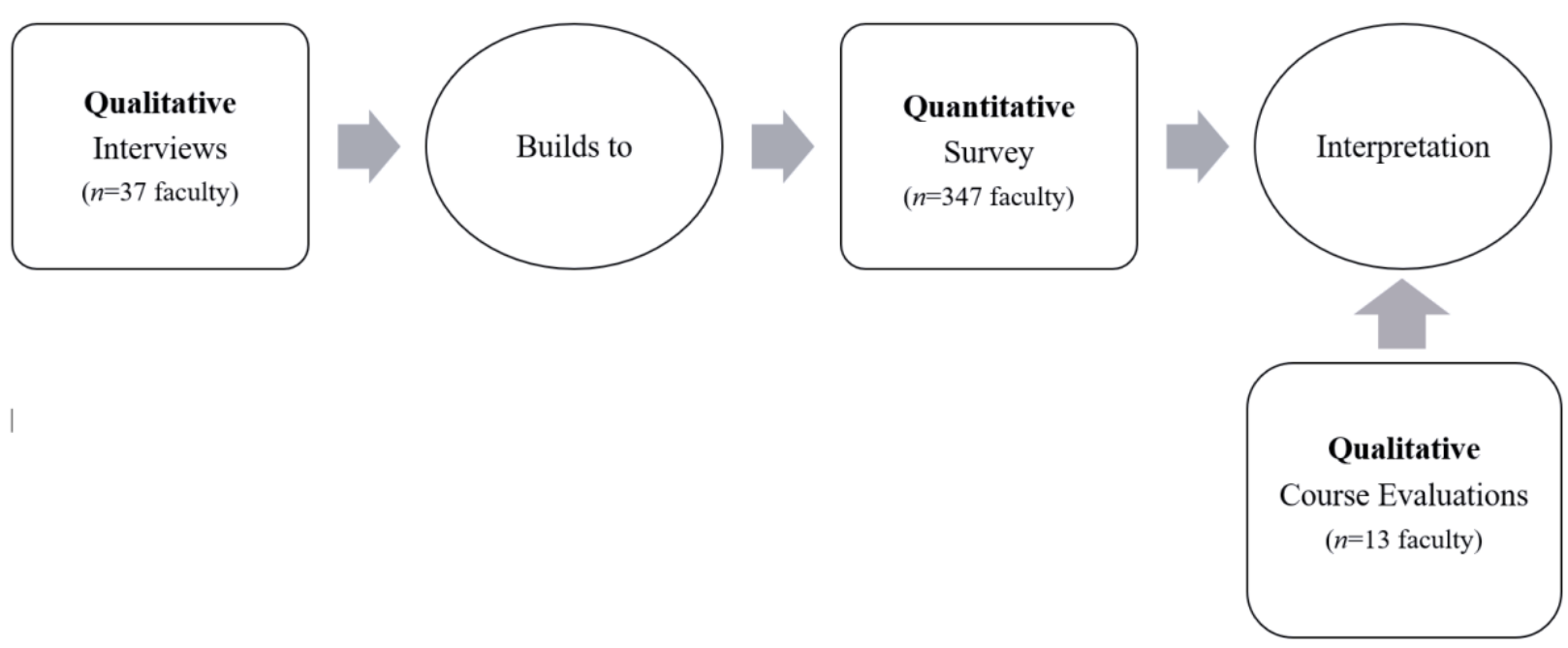

Note. This figure was adapted from Creswell and Plano Clark (2011).

We began by conducting semi-structured interviews with 37 faculty members about their experiences transitioning to online instruction at the beginning of the COVID-19 pandemic in spring 2020. Thirteen of these 37 instructors also shared their spring 2020 course evaluations, which provided students' perspectives on some courses. The practices that faculty described were used to develop survey items. For example, faculty participants discussed checking in with students to see how they were doing during the pandemic. Survey participants were then asked how often they "offer students opportunities to share how they are doing" when teaching online. In total, 347 faculty members completed the survey in fall 2020 . The survey data was used for complimenting the interview data. Figure 3 presents the research timeline.

\section{Researchers' Positionality}

We recognize that our backgrounds impact our research. We are a five-person research team, comprising three doctoral-level graduate students, one professor, and one senior administrator. Five additional faculty members and six additional graduate students offered feedback during the project as critical friends (Lincoln \& Guba, 1985). The team included 
experts in developmental psychology, educational psychology, curriculum and instruction, educational measurement, and higher education. Three of the five are scholars of color.

Figure 3

Research timeline

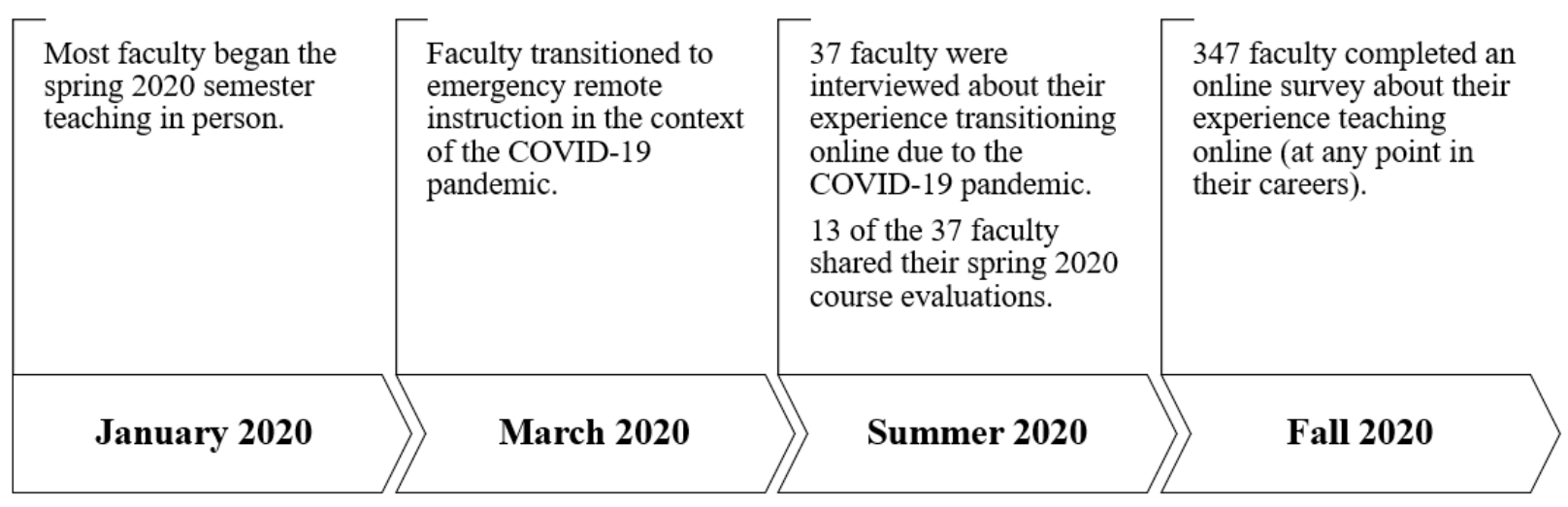

The course evaluation and survey data were used to triangulate findings from the interviews, increasing the trustworthiness of our findings (Merriam \& Tisdell, 2016). For example, students described practices in the course evaluations that were mentioned by instructors. Many survey participants described "often" or "very often" engaging in the practices described by faculty interview participants, suggesting that these reflected general campus practices.

\section{Participants}

We invited two sets of participants. The primary group included 37 participants whom we interviewed. In summer 2020, we recruited these faculty participants through purposive sampling using two criteria. First, school deans nominated faculty members who flourished in online learning. Second, nominated faculty had to volunteer to participate after receiving an invitation.

In total, 37 faculty members participated in interviews, including tenured, tenure-track, and non-tenure track faculty of varying ranks and years of experience. These faculty represented eight schools across the university. Some faculty teach undergraduates only $(n=16 ; 43 \%)$, some graduate students only $(n=11 ; 30 \%)$, or both $(n=10 ; 27 \%)$. Table A in the Appendix presents additional information about participants.

For the survey, we invited 1,865 instructors at the same university to participate in an online survey about their experiences with online teaching and learning in fall 2020;347 instructors started the survey and passed the screening question, which asked them whether they had ever taught online or in a hybrid/blended format, resulting in an overall response rate of $18.6 \%$. The number of participants answering each question dropped across the survey. Rather than limiting the survey to those who completed it, we used the data available for each question. In the middle of the survey, about 300 responded, and about 280 responded to the demographic questions at the end.

\section{Data Collection}

Data included interviews, course evaluations, and survey results. The interviews were conducted first, and preliminary interview findings informed survey instrument development (see Figure 4). 
Figure 4

Triangulation of data sources

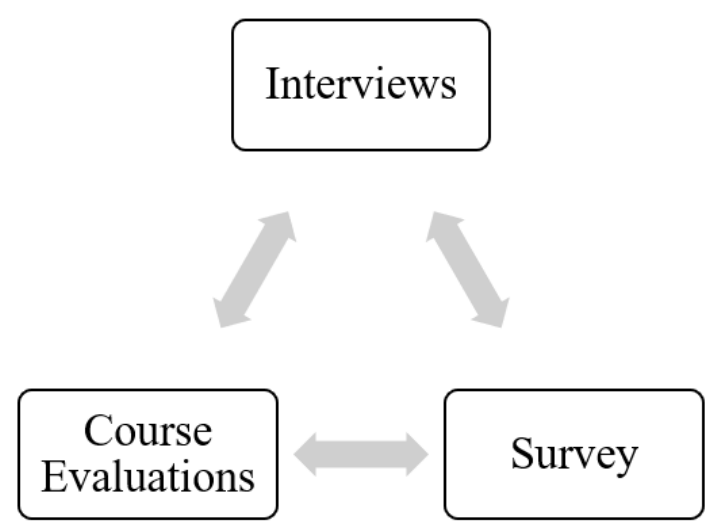

\section{Interviews}

Faculty participated in individual semi-structured Zoom interviews, each lasting approximately 60 minutes, conducted by one or two investigators. Questions focused on their teaching experience, including prior online teaching, the affordances of online education, how their online teaching might have changed their attitudes toward online teaching and learning, strategies to foster a sense of community online, and online teaching advice. See the Appendix for the interview questions. Interviews were recorded and transcribed. Participants were asked to review their transcripts for accuracy.

\section{Course Evaluations}

Students complete course evaluations each semester. In response to the COVID-19 pandemic, two open-ended responses were added to the spring 2020 evaluations:

(1) What are some of the benefits or advantages of taking this course remotely?

(2) What were some challenges in taking this course remotely?

Three additional questions are also included in the standard, pre-pandemic evaluation:

(3) What are the strengths of this course?

(4) How could the instructor improve the course?

(5) Would you recommend this course to other students, majors, etc.? Why or why not? Students' responses to these five questions, plus an open "additional comments" text box, were analyzed as part of this study. Thirteen of the 37 interview participants shared their spring 2020 course evaluations. These 13 faculties represented five of the eight schools: arts and sciences $(n$ $=8 ; 62 \%)$; business $(n=1 ; 8 \%)$; education $(n=2 ; 15 \%)$; social work $(n=1 ; 8 \%)$; and theology and ministry $(n=1 ; 8 \%)$.

\section{Survey}

The survey was administered online using Qualtrics and took approximately 25 to 30 minutes. Two experts outside the research team reviewed the questions and provided feedback. The survey asked about prior online teaching experience; overall satisfaction with teaching online; experience with learning management systems; utilization of video conferencing; and 
engagement in practices to support students' holistic development online. While most survey questions were closed-response, using Likert scales, four open-response questions were also included. All survey questions were designed for this study. As noted above, the interviews informed the survey development.

\section{Data Analysis}

Interview and course evaluation data were analyzed inductively, while survey data were analyzed using descriptive statistics.

\section{Interviews}

The semi-structured interview data were analyzed inductively and iteratively (Lincoln \& Guba, 1985). Our preliminary analysis involved analytic memo writing after each interview to capture initial reflections and brainstorm codes (Merriam \& Tisdell, 2016). We then transitioned to formal coding using Dedoose, following data analysis procedures from Miles et al. (2014): (a) reviewing a subset of data and determining initial codes (e.g., practices to increase student participation, student-student engagement, student-teacher engagement); (b) establishing definitions for all codes; (c) coding the data; (d) revising codes; (e) forming categories and subcategories from the thematic patterns (e.g., purposeful course design); (f) revising categories and subcategories; (g) repeating steps (d) through (f) iteratively; (h) renaming or shifting the categories and subcategories; and (i) conducting within- and cross-case analyses of the categories.

\section{Course Evaluations}

Open-response course evaluation questions were also analyzed inductively using Dedoose. The codes generated from the interview data were applied to the open-response course evaluation data.

\section{Survey}

The survey data were used to triangulate findings from the current study. The statistical analyses are exploratory and descriptive in nature. Analyses involved computing frequencies and percentages for individual survey items (i.e., the percent of faculty who "often" engaged in specific teaching practices). See the Appendix for specific items and the associated response options.

\section{Findings}

The findings showed (1) intentional and purposeful course design, (2) establishing clear expectations, and (3) fostering supportive and trustworthy classroom environments to create community online during the COVID pandemic. Additional subthemes are presented below. To implement these strategies, faculty used tools such as Zoom breakout rooms, polling, and the Canvas asynchronous group discussion board. These tools not only enhanced student participation, but also provided an opportunity for voices to be heard.

Many instructors in our study were teaching online for the first time. Only $16 \%$ of survey respondents had taught at least one completely online course before the pandemic. Hence the transition to online education represented a significant shift in professional practice. Despite their limited online experience, faculty in our study used several strategies to create a positive sense of community online; $88 \%$ of survey respondents reported that they "often" or "very often" "strive to create a sense of community in the classroom" when teaching online.

\section{Intentional and Purposeful Course Design}

Many faculty members purposefully designed online courses to improve their teaching presence. Faculty were acutely aware of their responsibility to establish a positive online 
experience. As Kristina explained, "I'm the node, and then you've got all these people that come off that node and there are some connections between them." For the class to have a successful, productive remainder of the semester, Kristina needed to be the glue holding the community together. "And so I think that for the community... it's not like the community existed on its own. It was a community that existed through me, right?" Faculty members provided a reassuring connection to campus, in the context of a pandemic when students were abruptly sent home.

From a different perspective, Jordan described himself as a "co-learner" in the classroom community. He elaborated:

I understand us to be co-learners and so we're sharing in the process. And I think to the degree to which I can do that with authenticity, then, that's the degree to which they recognize me as a learner as well. And if I'm a learner then that helps to form the community.

While Kristina positioned herself as the lead actor within the online classroom space, Jordan envisioned himself as another group member. Despite differences in their imagined roles, both instructors established a successful teaching and social presence. And both were aware of the pivotal role they played in the classroom community.

When adjusting to online teaching, faculty made deliberate pedagogical decisions to foster their teaching presence and support their students' developmental needs. Beatrice described her course design process as follows:

I am always thinking about how to create the kind of classroom experience... that gets them connecting with the world around them and in relationships that are meaningful. How am I going to do that in their interactions with each other, whether it's like through certain kinds of activities and breakout rooms, the nature of my prompts, the ways that they're timed and so on. All of those things are considered. Because I'm trying to create an environment that honors their psychological and social needs.

Beatrice's pedagogy focused on building a strong classroom community and supporting students' development. In an online environment, this involved synchronous Zoom breakout room activities and asynchronous activities outside class time. Beatrice's emphasis on "timing" conveys the careful choreography that characterized her teaching.

\section{Establishing Clear Expectations}

The second theme involved faculty establishing clear expectations about what students and instructors should expect from each other. Faculty recognized that students were anxious about online courses. Especially during the crisis, a clear structure for the remainder of the semester was reassuring. For example, immediately after receiving notification that courses would be moved online, Grant emailed students an updated syllabus, providing reassurance that there was a plan.

Faculty also established norms for how they expected students to engage in synchronous sessions, such as encouraging students to turn on their cameras. Samuel explained:

"In order for you to learn well in this environment, I expect the following things of myself and of you." And I had these you know-I said on my slides, "I'm going to be on time to 
class, I'm going to be prepared. I'm going to carry on with class exactly the same way as I do normally. I have PowerPoints in every class," and all that sort of stuff. And I also set my expectations are that you arrive in the classroom a couple minutes early, that your video camera is on, that you stay in touch with me if there's some reason why you can't participate, etc. I think those were all ways of getting us all on the same page as to what my expectations were for us as a group. And that creates a sense of community.

By outlining clear expectations and prioritizing "getting us all on the same page," Samuel demonstrated his respect for students and the courtesy he expected students to show. This mutual respect provided a foundation for community.

Marcus did not establish guidelines similar to Samuel's, but by the end of the semester he recognized the importance of clear expectations:

One thing that I felt that I would do differently in the Fall, if I'm teaching online at all, would be more sensitive to really requesting or enforcing everyone have their audio and video on. [...] Because I did have like two or three students who they were there, but then you know, they just had a picture up and their sound was muted and then sometimes you would call on them or say something and nobody responded.

Marcus described how, when nobody responded, it created an awkward moment. Marcus wondered if the student had left the Zoom meeting. Alternatively, the student might have limited internet bandwidth. When expectations are established from the beginning, students can inform the professor of any internet-related challenges.

\section{Fostering Supportive and Trustworthy Classroom Environments}

As students encountered difficulties transitioning into online learning, faculty members emphasized the importance of supportive and trustworthy environments. Kelly noted: "We can't jump right into content without some serious community building." Creating a supportive online community involved integrating technology. As discussed below, features like breakout rooms were frequently described as useful for community. Faculty also used Zoom to hold office hours and meetings with students. Figure 5 provides an overview of how survey participants utilized video conferencing tools. The highest proportion of instructors used these tools for individual student meetings (92\%), while just under half used video for guest lectures (46\%). Specific examples of how instructors used these tools appear below.

Faculty replicated aspects of the in-person classroom experience using technology. Before the pandemic, Deborah's students were easily able to ask exam-related questions. She imitated the classroom environment by creating a Zoom meeting where they could quietly address their questions:

What they did is they checked [in] and they left their tile with no audio and no video, but if they had a question, I could answer it right there. And everybody else in the class could hear the question being asked too. And so, it was kind of like simulating the classroom a little bit.

While teaching online, Deborah was able to partially replicate the feeling of taking an exam together in a classroom. 
Figure 5

How instructors used video conferencing tools during the COVID-19 pandemic: Faculty survey $(n=292)$.

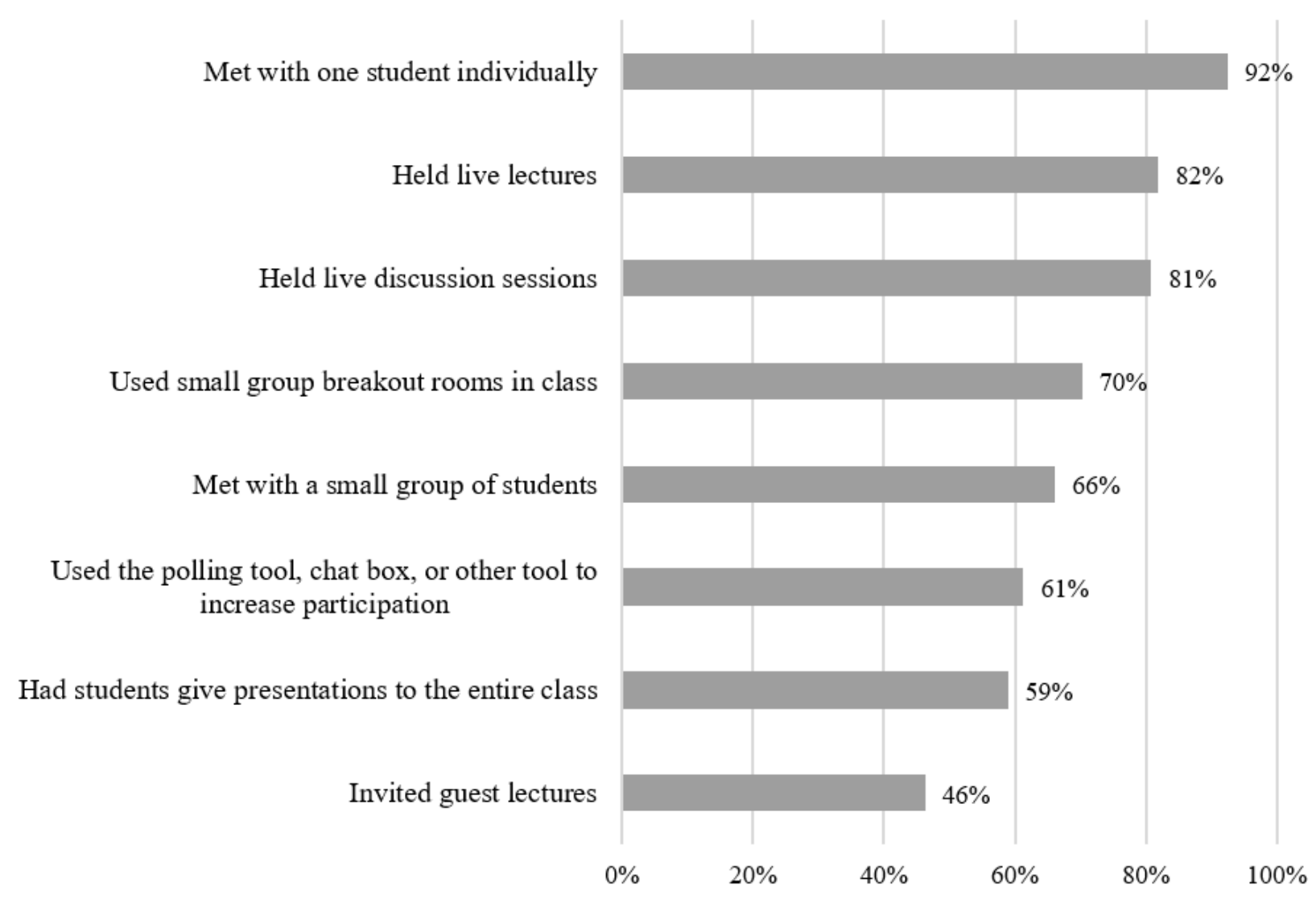

\section{Faculty-Student Interactions}

Positive interactions between faculty and students are crucial to supportive environments. Despite challenges they encountered in their own lives, faculty were readily available to students; $96 \%$ of survey respondents reported that they were "often" or "very often" "accessible to [their] students through a variety of means (drop-in, office hours, email, before or after class)." Instructors were attentive to students' needs, with $78 \%$ reporting that they "often" or "very often" "modify [their] course to accommodate students' feedback about what is working well in the course and what could use improvement" and 76\% "often" or "very often" "modify [their] course to accommodate [their] students' needs." Alex noted how students often requested that class discussions begin with a small group component, allowing them to process their thoughts in groups before transitioning to class.

Faculty also cultivated relationships with students by prioritizing their social-emotional needs. Maxine described her approach as emphasizing the "human connection"; "My primary concern was caring about them and helping them get through this." Faculty regularly checked in with their students. Alex noted, "For the first few weeks, just be really on top of making sure you're reaching out to every student individually all the time. Because that's going to make them 
feel recognized." Beatrice described her approach to mentoring students as "tenaciously caring" about them, even "chasing" after them when necessary.

Faculty deliberately engaged with students who were struggling. Several participants contacted students when they noticed a change in their academic engagement. Survey respondents also showed similar concern for students, with $76 \%$ reporting that they "often" or "very often" "contact students who fall behind in class to offer support." Grant stressed that this outreach was done in a "very empathetic" way, "kind of giving them opportunities just to keep getting things in to me and to re-engage." In other words, it was not meant to be punitive. Similarly, Deborah described reaching out to students when she noticed their grades drop. "The biggest takeaway is that you can't be reaching out too much. [...] The students do want you to reach out, be there for them." Especially during the pandemic, when students were encountering additional mental health concerns, it was important for faculty to demonstrate their care for students as whole people. $93 \%$ of survey respondents "often" or "very often" "make sure each student feels valued."

Some instructors established check-ins with their students in the minutes preceding class, during class, or immediately after class. Just under two-thirds (64\%) of survey respondents reported that they "often" or "very often" "offer students opportunities to share how they are doing." Several interview participants asked each student to share their weekly "highs and lows." For example, Andrea took notes on information that students shared in class: "I'd follow up with emails for some of them later. Like one [who] was COVID positive was used in a plasma study. I was like, 'That's awesome.' That was his high. He could help other people." Andrea was thinking about her students outside class.

Faculty members believed it was especially important to contact certain vulnerable or disconnected populations, such as international students and students from lower-income families. Deborah said "making sure that my international students who were home felt comfortable" was very important, as she recognized that they were likely feeling isolated. Since most international students were in other time zones, it was difficult to attend synchronous classes. Considering international students' needs, Grant recorded his lectures and held additional online office hours in the late evening. Melanie offered to meet one-on-one with an international student each week to discuss the course.

Faculty members were also concerned about less socioeconomically privileged students. Kristen described her check-ins with a student she was especially worried about:

One [student] was from a fairly disadvantaged background and he was emailing me saying, "I'm really sorry. I Zoomed into class late. I was helping my mom with something, and she really needed me with her. She's afraid she's going to get fired and I was helping her with her Zoom."

In addition to classes, Kristen's student also juggled family responsibilities. Some students had to choose between participating in their classes and attending to family concerns. Melanie noted that returning home and taking the class online "exaggerated inequality to some extent." Faculty recognized how challenging the pandemic was for vulnerable students and proactively supported them.

\section{Student-Student Interactions}

Faculty used several strategies to create opportunities for students to engage, communicate, and collaborate. The survey results indicated that $70 \%$ of the instructors "often" or 
"very often" "provide students opportunities to get to know their classmates." Faculty facilitated student interactions through small group activities and creative technology use.

Small Group Activities. Several faculty members divided students into smaller communities or "family groups," as Rachel called them, within the larger classroom. Sixty-seven percent of survey respondents reported that when teaching online they "often" or "very often" "create opportunities for students to work in pairs or smaller groups that allow collaborations and more personal connections." Rachel held weekly meetings with each "family group" to discuss the class readings and their projects. When not meeting with Rachel, these student groups participated in discussion board conversations during class time. By working towards a shared goal on a group project, Eleanor explained that students "learn to rely on each other...and develop their sense of community, their sense of agency." Beatrice thought assigning students to communities was like sorting people into houses in Harry Potter: "We're a society here; we're a club; we are a team; and we're for each other." The smaller groups allowed students to establish camaraderie with classmates.

One goal of these small group activities was offering students space to develop their autonomy as learners. Despite the important role teachers play in establishing social presence, Lisa acknowledged that sometimes it is better for teachers to step aside:

Giving students a little more space to go out there and connect in their own ways, or even in the break-out rooms to talk to one another [...] and thinking about the fact that community doesn't always have to be a) the whole class and b) facilitated by me. [...] Getting students to a point where they feel like there's enough of a community that if you need to step aside, they can keep things going.

Lisa's statement suggests that fostering optimal classroom communities involves empowering students to establish community and engage with the content among themselves.

Creative Utilization of Technology. Technology played a critical role in fostering students' engagement with their peers. In particular, Zoom breakout rooms provided opportunities for students to interact with peers in small groups. For example, Grant remarked:

I really use the breakout groups heavily to try to give them a chance to talk to each other about what was going on or about how class related to what's going on. Or to discuss the ethical implications of things we're going to cover.

Using breakout rooms separates students into groups that are small enough for students to feel comfortable speaking up. Alex explained that a common theme from prior course evaluations was that students wanted opportunities to interact with a wider range of classmates. When teaching online, Alex assigned students to breakout rooms randomly, allowing students to interact with peers. Kelly added that the breakout rooms fostered "social cohesion" and allowed for "really personal or deep" conversations.

Faculty also used polling tools to foster a sense of community; $61 \%$ of survey respondents used polling tools, chat boxes, or other tools to increase student participation. As Samuel explained: 
I did a lot of poll questions-which I think is also good for community, because you can see how other people voted. [...] Sometimes my poll questions were fun. So, I stayed [in the northeast], it snowed in [the northeast] in April. And I made this joke that I was horrified to see that it was snowing last night. "How many people did it snow for last night?" And I had a poll question at the start of the class. And it's just a fun little thing that like, everyone can smile, it makes everyone feel like they're a part of something. And then afterwards, I don't know, maybe they're talking about it on their WhatsApp group or whatever, you know?

Not only did the polling tools increase participation, but they also fostered community by allowing students to see what their peers were thinking about. In other instances, the polling questions were not related to the course content but were designed to facilitate camaraderie among students. Samuel appreciated how his students might continue discussing the poll topic even after class.

Faculty members also used online discussion boards in the learning management system to facilitate peer interactions. Discussion boards allowed students to provide one another feedback. As Melanie explained:

I also had students write things on Canvas [discussion boards] to one another [...] I had them read each other's works [...] and then give each other feedback. And those were all designed not only to help them have better projects, but to help them build community, just so that they would continue to share with one another.

Like Samuel, Melanie believed that opportunities for students to know what their peers were thinking and respond to others' academic work was critical to community. Marcus added that discussion boards not only support students' content acquisition but also provide opportunities for students to develop communication skills: "How do you listen well? How do you have a charitable interpretation of your interlocutors? How do we ask good questions of one another?" Strong communities require listening to one another's ideas and responding respectfully.

\section{Incorporating Community Outside the Classroom}

Faculty incorporated students' family and home lives into the classroom experience. At the beginning of each synchronous session, Kristen asked one student to either share their favorite photo or location at home, or introduce the class to a pet, parent, sibling, or other family member. This practice allowed students to share personal aspects of themselves with their teacher and classmates. Another professor deliberately included parents in conversations. Curt explained:

I also understood that most of the students were at home, cooped up with their parents, and both parties were a little bit frustrated, not only the students, but parents were also anxious. So I started to have live Zoom sessions for parents only. So yes, I met with parents and I had great conversations with them. I put them at ease.

The online environment opened the classroom to students' parents. This increased access might have provided opportunities for students to discuss course content with their families.

Eleanor described incorporating her family into the classroom. She described a situation where students asked several questions in the discussion board that she felt her brother and 
sister-in-law, both physicists, were better equipped to answer. Eleanor then contacted her family to answer the students' questions. Eleanor's practice exemplifies how the effective use of technology in online courses can improve upon the in-person experience by making it easier to incorporate voices from outside the immediate classroom, productively exposing students to voices outside the university. This last subtheme was the only theme that was not reflected in the course evaluation data. It is possible that interactions outside the classroom were less important to students compared to instructors.

\section{Discussion}

The COVID-19 pandemic brought unprecedented disruption to higher education. This mixed methods study illuminates how faculty at one residential university supported students' holistic needs during the pandemic by creating strong online communities. While previous studies have typically focused on students' perceptions of community online, this study provides insights regarding how the faculty perceive their own roles in supporting the development of an online community and what strategies they use. Most prior studies that have incorporated faculty perspectives focus on courses designed for online environments rather than emergency online instruction. In comparison, our faculty interview participants began the spring 2020 semester in person, without any expectation of teaching online, and their online work was improvised.

In some respects, beginning the semester in person might have provided an advantage with respect to community building, since faculty and students had about seven weeks to establish connections with one another in the physical classroom. At the same time, the online course experience might have been viewed from a deficit perspective, citing what was "lost" compared to the traditional classroom experience. Certain components of the in-person experience were lost. For example, as one faculty member in our study noted, the types of spontaneous interactions that occur in person are difficult to replicate online. But the classrooms we heard about also gained from the online environment in some ways.

Despite the challenges of abruptly moving courses online, the 37 faculty we interviewed demonstrated a strong commitment to supporting community online, as did most survey respondents. Faculty members' strategies for building community centered around intentional and purposeful course design; establishing clear expectations for themselves and their students; and fostering supportive and trustworthy classroom environments. In implementing these strategies, faculty established a strong teaching presence in the online classroom (Garrison et al., 2010; Garrison \& Akyol, 2013), the binding CoI presence that supported both social and cognitive presences (Shea \& Bidjerano, 2009). One faculty member even described herself as the "node" or glue holding the class together during these precarious times. These strategies are represented in Figure 6 and show how instructors interact with students, how instructors foster relationships among students, and how instructors foster connections with participants outside the community. 
Figure 6

Model of online community interactions

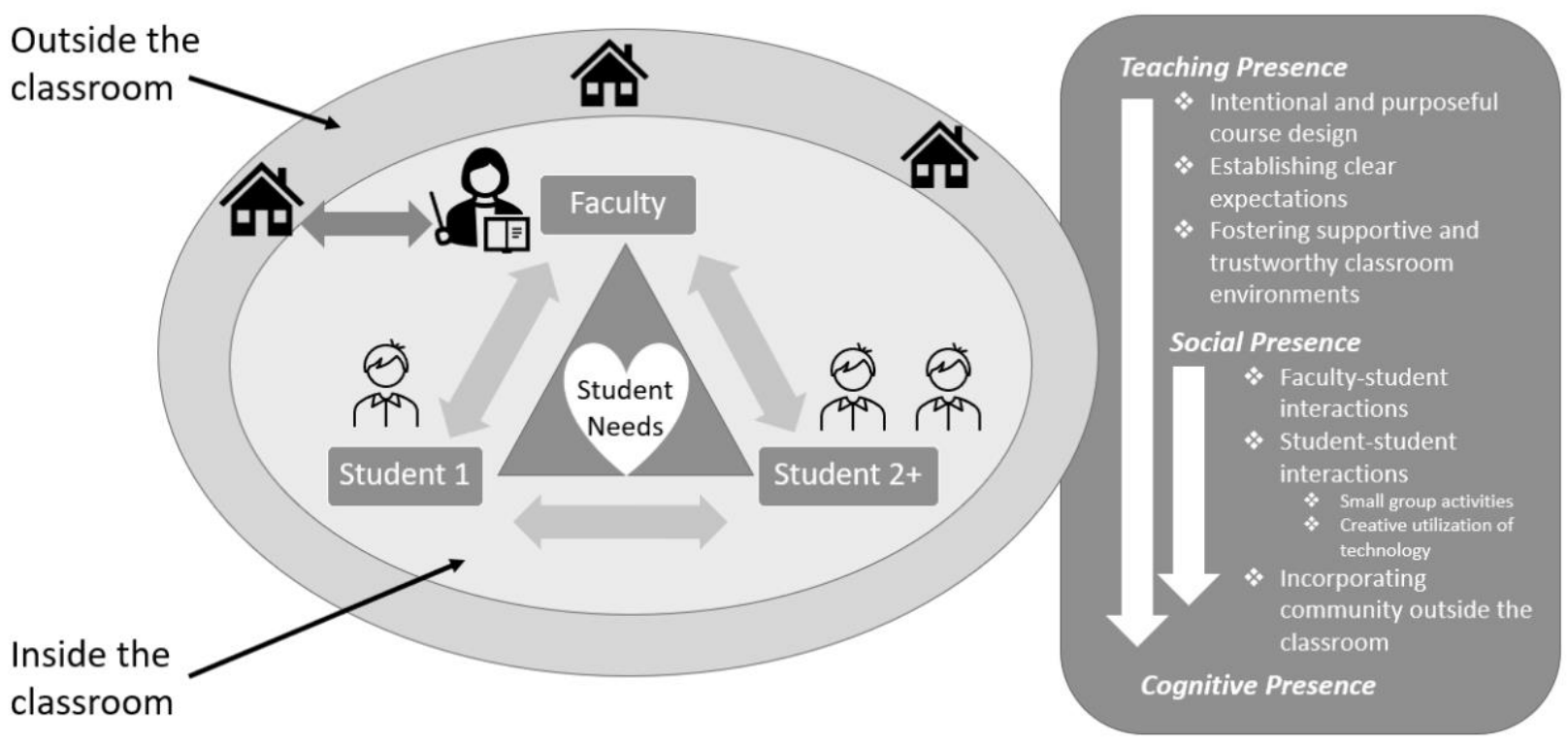

Faculty in our study adopted multiple roles, including course manager and course facilitator, while taking seriously their mentoring role (Martin et al., 2019). Considering the ongoing pandemic and the associated stresses, faculty were attuned to students' social-emotional needs (Kuh, 2018). One professor described how she "tenaciously cared" for her students (Goin Kono \& Taylor, 2021). This prioritization of social-emotional needs suggests that the intersection of teaching and social presences might be especially important in emergency remote instructional contexts (Conklin \& Dikkers, 2021).

Fostering interpersonal relationships in virtual environments is essential to students' learning (Strayhorn, 2019; Whipp \& Lorentz, 2009). The faculty members in our study show how it is possible to create learning communities that replicate critical aspects of the on-campus environment that have long been recognized as essential for student success (Astin, 1999; Museus, 2014; Pascarella \& Terenzini, 2005; Tinto, 1998). For example, faculty can establish strong, supportive relationships with students online by checking in on their students' emotional well-being, responding to students' feedback, and meeting individually with students. Students can develop relationships with one another through small group meetings in breakout rooms and by responding respectfully to one another's ideas on discussion boards.

While these relational aspects of the college student experience will not be the same as the in-person experience, with reflection and purposeful design they can be similar-or in some respects even better. For instance, with respect to students' families, prior research indicates that students' family relationships contribute to their sense of campus belonging, especially among certain populations like transfer students (Lester et al., 2013). Some faculty in our study established relationships with students' families when teaching online. This type of engagement 
between students' families and professors is not as easily accomplished in person. Thus, online education might offer opportunities to increase belongingness and a sense of community among some student populations.

\section{Limitations and Future Directions}

While this study illuminates online community building, there are some limitations, as well as directions for future research. First, both the survey and interview respondents came from the same university. It is possible that these findings are not generalizable. Second, although our survey sample was generally representative of the university population, there might have been some selection bias in terms of who responded. More specifically, faculty with an interest in sharing their experiences teaching online might have had more positive experiences compared to those not responding to the survey. Third, we cannot evaluate the extent to which the strategies faculty utilized online to support community might have been different had this study been conducted outside the pandemic or if the faculty members did not have opportunities to interact with students in the first half of the spring 2020 semester. This latter point is less relevant for the survey respondents, as the survey was conducted in fall 2020. The alignment between the interview and survey findings provides some indication that the community building practices discussed by interview participants would occur even without the face-to-face in-person component.

We propose several directions for future research. First, we recommend that future studies examine community development online across a broader range of institutions to evaluate the extent to which findings are generalizable. Researchers could retrospectively interview and/or survey faculty about their experience building community online during the global pandemic. Second, future research could examine whether there are disciplinary differences (e.g., chemistry versus history) or differences based on course level (e.g., undergraduate versus graduate) concerning how faculty build community online. Finally, additional research should explore students' perceptions of community online during the pandemic. It is important to explore whether online community building strategies and outcomes differ by student demographics and characteristics. These three lines of inquiry will provide further insight on community building in online environments, increasing the generalizability of our findings and the diversity of voices represented. 


\section{References}

Archibald, D. (2010). Fostering the development of cognitive presence: Initial findings using the community of inquiry survey instrument. Internet \& Higher Education, 13(1/2), 73-74. https://doi.org/10.1016/j.iheduc.2009.10.001

Astin, A. W. (1999). Student involvement: A developmental theory for higher education. Journal of College Student Development, 40(5), 518-529.

Baker, C. T., \& Edwards, J. T. (2011). A holistic approach for establishing social presence in online courses and programs. The International HETL Review, 1(7), 44-52.

Baxter Magolda, M. B. (2020). Making their own way: Narratives for transforming higher education to promote self-development [Kindle edition]. Stylus Publishing, LLC.

Berry, S. (2017). Building community in online doctoral classrooms: Instructor practices that support community. Online Learning, 21(2), n2. http://dx.doi.org/10.24059/olj.v21i2.875

Berry, S. (2019). Teaching to connect: Community-building strategies for the virtual classroom. Online Learning, 23(1), 164-183. http://dx.doi.org/10.24059/olj.v23i1.1425

Castañeda, L., \& Selwyn, N. (2018). More than tools? Making sense of the ongoing digitizations of higher education. International Journal of Educational Technology in Higher Education, 15(1), 22. https://doi.org/10.1186/s41239-018-0109-y

Chickering, A. W., \& Reisser, L. (1993). Education and identity (2nd ed.). Jossey-Bass Inc.

Conklin, S., \& Garrett Dikkers, A. (2021). Instructor social presence and connectedness in a quick shift from face-to-face to online instruction. Online Learning, 25(1), 135-150. https://doi.org/10.24059/olj.v25i1.2482

Creswell, J. W., \& Clark, V. L. P. (2011). Designing and conducting mixed methods research (2nd ed.). Sage.

Garrison, D. R., \& Akyol, Z. (2013). The community of inquiry theoretical framework. In M. G. Moore (Ed.), Handbook of distance education (3rd ed.) (pp. 104-119). Routledge.

Garrison, D. R., Anderson, T., \& Archer, W. (1999). Critical inquiry in a text-based environment: Computer conferencing in higher education. The Internet and Higher Education, 2(2-3), 87-105. https://doi.org/10.1016/S1096-7516(00)00016-6

Garrison, D. R., Anderson, T., \& Archer, W. (2010). The first decade of the community of inquiry framework: A retrospective. The Internet and Higher Education, 13(1), 5-9. https://doi.org/10.1016/j.iheduc.2009.10.003 
Goin Kono, K., \& Taylor, S. (2021). Using an ethos of care to bridge the digital divide: Exploring faculty narratives during a global pandemic. Online Learning, 25(1), 151-165. https://doi.org/10.24059/olj.v25i1.2484

Goldrick-Rab, S., Coca, V., Kienzl, G., Welton, C. R., Dahl, S., \& Magnelia, S. (2020). \#RealCollege during the pandemic: New evidence on basic needs insecurity and student wellbeing. The Hope Center.

Grant, C. A. (2012). Cultivating flourishing lives: A robust social justice vision of education. American Educational Research Journal, 49(5), 910-934. https://doi.org/10.3102\%2F0002831212447977

Hart, C. M. D., Xu, D., Hill, M., \& Alonso, E. (2021). COVID-19 and community college instructional responses. Online Learning, 25(1), 41-69. https://doi.org/10.24059/olj.v25i1.2568

Healthy Minds Network, \& American College Health Association. (2020). The impact of COVID-19 on college student well-being. https://healthymindsnetwork.org/wpcontent/uploads/2020/07/Healthy_Minds_NCHA_COVID_Survey_Report_FINAL.pdf

Hodges, C., Moore, S., Lockee, B., Trust, T., \& Bond, A. (2020). The difference between emergency remote teaching and online learning. Educause Review, 27, 1-12.

Inside Higher Ed. \& Gallup. (2018). The 2018 Inside Higher Ed Survey of faculty attitudes on technology: A study by Gallup and Inside Higher Ed. https://mediasite.com/wpcontent/uploads/2018/11/2018-Faculty-Survey-Mediasite.pdf

Kauffman, H. (2015). A review of predictive factors of student success in and satisfaction with online learning. Research in Learning Technology, 23, 26507. https://doi.org/10.3402/rlt.v23.26507

Kilgour, P., Reynaud, D., Northcote, M., McLoughlin, C., \& Gosselin, K. P. (2019). Threshold concepts about online pedagogy for novice online teachers in higher education. Higher Education Research \& Development, 38(7), 1417-1431. https://doi.org/10.19173/irrodl.v14i1.1338

Kim, D., Wortham, S., Borowiec, K., Yatsu, D. K., Ha, S., Carroll, S., Wang, L., \& Kim, J. (2021). Formative education online: Teaching the whole person during the global COVID-19 pandemic. AERA Open, 7(1), 1-12. https://doi.org/10.1177\%2F23328584211015229

Kuh, G. (2018). Whither holistic student development: It matters more today than ever. Change: The Magazine of Higher Learning, 50(3-4), 52-57. https://doi.org/10.1080/00091383.2018.1509590

Lester, J., Brown Leonard, J., \& Mathias, D. (2013). Transfer student engagement: Blurring of social and academic engagement. Community College Review, 41(3), 202-222. https://doi.org/10.1177\%2F0091552113496141 
Lincoln, Y. S., \& Guba, E. G. (1985). Establishing trustworthiness. Naturalistic

Inquiry, 289(331), 289-327.

Love, P. G., \& Love, A. G. (1995). Enhancing student learning: Intellectual, social, and emotional integration (ASHE-ERIC Higher Education Report No. 4). ASHE. https://files.eric.ed.gov/fulltext/ED400742.pdf

Lowenthal, P. R., \& Dunlap, J. C. (2018). Investigating students' perceptions of instructional strategies to establish social presence. Distance Education, 39(3), 281-298. https://doi.org/10.1080/01587919.2018.1476844

Martin, F., Ritzhaupt, A., Kumar, S., \& Budhrani, K. (2019). Award-winning faculty online teaching practices: Course design, assessment and evaluation, and facilitation. The Internet and Higher Education, 42, 34-43. https://doi.org/10.1016/j.iheduc.2019.04.001

Mayhew, M. J., Rockenbach, A. N., Bowman, N. A., Seifert, T. A., \& Wolniak, G. C. (2016). How college affects students: 21 st century evidence that higher education works (Vol. 1). John Wiley \& Sons.

McInnerney, J. M., \& Roberts, T. S. (2004). Online learning: Social interaction and the creation of a sense of community. Journal of Educational Technology \& Society, 7(3), 73-81. https://www.jstor.org/stable/10.2307/jeductechsoci.7.3.73

McMillan, D. W., \& Chavis, D. M. (1986). Sense of community: A definition and theory. Journal of Community Psychology, 14(1), 6-23. https://doi.org/10.1002/1520 6629(198601)14:1\%3C6::AID-JCOP2290140103\%3E3.0.CO;2-I

Means, B., \& Neisler, J. (2021). Teaching and learning in the time of COVID: The student perspective. Online Learning, 25(1), 8-27. https://doi.org/10.24059/olj.v25i1.2496

Merriam, S. B., \& Tisdell, E. J. (2016). Qualitative research: A guide to design and implementation (4th ed.). Jossey-Bass.

Miles, M. B., Huberman, A. M., \& Saldaña, J. (2014). Qualitative data analysis: A methods sourcebook (3rd ed.). Sage.

Miller, K.E. (2021). A light in students' lives: K-12 teachers' experiences (re)building caring relationships during remote learning. Online Learning, 25(1), 115-134.

https://doi.org/10.24059/olj.v25i1.2486

Museus, S. D. (2014). The culturally engaging campus environments (CECE) model: A new theory of success among racially diverse college student populations. In Higher education: Handbook of theory and research (pp. 189-227). Springer. 
Oliphant, T., \& Branch-Mueller, J. (2016). Developing a sense of community and the online student experience. Education for Information, 32(4), 307-321._https://doi.org/10.3233/EFI160979

Ouyang, F., \& Scharber, C. (2017). The influences of an experienced instructor's discussion design and facilitation on an online learning community development: A social network analysis study. The Internet and Higher Education, 35, 34-47.

https://doi.org/10.1016/j.iheduc.2017.07.002

Pascarella, E. T., \& Terenzini, P. T. (2005). How college affects students: A third decade of research (1st ed.). Jossey-Bass.

Patton, L. D., Renn, K. A., Guido, F. M., \& Quaye, S. J. (2016). Student development in college: Theory, research, and practice. John Wiley \& Sons.

Quezada, R. L., Talbot, C., \& Quezada-Parker, K. B. (2020). From bricks and mortar to remote teaching: a teacher education programme's response to COVID-19. Journal of Education for Teaching, 1-12. https://doi.org/10.1080/02607476.2020.1801330

Radford, A. W. (2011). Learning at a distance: Undergraduate enrollment in distance education courses and degree programs: Stats in Brief (NCES 2012-154). National Center for Education Statistics. https://nces.ed.gov/pubs2012/2012154.pdf

Robinson, C. C., \& Hullinger, H. (2008). New benchmarks in higher education: Student engagement in online learning. Journal of Education for Business, 84(2), 101-109. https://doi.org/10.3200/JOEB.84.2.101-109

Rovai, A. P. (2000). Building and sustaining community in asynchronous learning networks. The Internet and Higher Education, 3(4), 285-297. https://doi.org/10.1016/S1096-7516(01)00037-9

Rovai, A. P., \& Jordan, H. (2004). Blended learning and sense of community: A comparative analysis with traditional and fully online graduate courses. The International Review of Research in Open and Distributed Learning, 5(2), 1-13. https://doi.org/10.19173/irrodl.v5i2.192

Salmon, G. (2011). E-moderating: The key to teaching and learning online (3rd ed.). Routledge.

Shea, P., \& Bidjerano, T. (2009). Community of inquiry as a theoretical framework to foster "epistemic engagement" and "cognitive presence" in online education. Computers \& Education, 52(3), 543-553. https://doi.org/10.1016/j.compedu.2008.10.007

Shea, P., Li, C. S., \& Pickett, A. (2006). A study of teaching presence and student sense of learning community in fully online and web-enhanced college courses. The Internet and Higher Education, 9(3), 175-190. https://doi.org/10.1016/j.iheduc.2006.06.005 
Shea, P., Li, C. S., Swan, K., \& Pickett, A. (2005). Developing learning community in online asynchronous college courses: The role of teaching presence. Journal of Asynchronous Learning Networks, 9(4), 59-82. http://dx.doi.org/10.24059/olj.v9i4.1779

Song, L., Singleton, E. S., Hill, J. R., \& Koh, M. H. (2004). Improving online learning: Student perceptions of useful and challenging characteristics. The Internet and Higher Education, 7(1), 59-70. https://doi.org/10.1016/j.iheduc.2003.11.003

Stolzenberg, E. B., Aragon, M. C., Romo, E., Couch, V., McLennan, D., Eagan, M. K., \& Kang, N. (2020). The American freshman: National norms fall 2019. Higher Education Research Institute, UCLA.

Strayhorn, T. L. (2019). College students' sense of belonging: A key to educational success for all students (2nd ed.). Routledge.

Tinto, V. (1998). Colleges as communities: Taking research on student persistence seriously. The Review of Higher Education, 21(2), 167-177.

Tryon, P. J. S. van, \& Bishop, M. J. (2009). Theoretical foundations for enhancing social connectedness in online learning environments. Distance Education, 30(3), 291-315. https://doi.org/10.1080/01587910903236312

U.S. Department of Education, National Center for Education Statistics. (2019). Digest of education statistics 2019, Table 311.15. https://nces.ed.gov/fastfacts/display.asp?id=80

Wei, C. W., \& Chen, N. S. (2012). A model for social presence in online classrooms. Educational Technology Research and Development, 60(3), 529-545.

https://doi.org/10.1007/s11423-012-9234-9

Whipp, J. L., \& Lorentz, R. A. (2009). Cognitive and social help giving in online teaching: An exploratory study. Educational Technology Research and Development, 57(2), 169-192. https://doi.org/10.1007/s11423-008-9104-7

Wortham, S., Love-Jones, R., Peters, W., Morris, S., \& García-Huidobro, J. C. (2020). Educating for comprehensive well-being. ECNU Review of Education, 3(3), 406-436.

Zhai, Y., \& Du, X. (2020). Addressing collegiate mental health amid COVID-19 pandemic. Psychiatry Research, 288, 113003. https://doi.org/10.1016/j.psychres.2020.113003 


\section{Appendix}

Table A

Faculty Participant Names and Characteristics

\begin{tabular}{|c|c|c|c|}
\hline $\begin{array}{c}\text { Faculty } \\
\text { Participant } \\
\text { (pseudonym) }\end{array}$ & School (pseudonym) & General Discipline & Teaching Level \\
\hline Adam & Theology and Ministry & Theology/Ministry & Graduate \\
\hline Alejandro & Social Work & Social Work & Graduate \\
\hline Alex & Arts and Sciences & Humanities & Undergraduate \\
\hline Andrea & Business & Business & Undergraduate \\
\hline Beatrice & Education & Counseling/Psychology & Both \\
\hline Carol & Theology and Ministry & Theology/Ministry & Graduate \\
\hline Caroline & Social Work & Social Work & Graduate \\
\hline Chloe & $\begin{array}{l}\text { Adult and Continuing } \\
\text { Education }\end{array}$ & Professional Studies & Graduate \\
\hline Curt & Arts and Sciences & Social Sciences & Both \\
\hline David & Law & Law & Graduate \\
\hline Deborah & Arts and Sciences & STEM & Undergraduate \\
\hline Eleanor & Arts and Sciences & STEM & Undergraduate \\
\hline Garrett & $\begin{array}{l}\text { Adult and Continuing } \\
\text { Education }\end{array}$ & Professional Studies & Graduate \\
\hline Grant & Arts and Sciences & Social Sciences & Undergraduate \\
\hline $\begin{array}{l}\text { Jacob } \\
\text { Jasmine }\end{array}$ & $\begin{array}{c}\text { Business } \\
\text { Arts and Sciences }\end{array}$ & $\begin{array}{l}\text { Business } \\
\text { STEM }\end{array}$ & $\begin{array}{c}\text { Undergraduate } \\
\text { Both }\end{array}$ \\
\hline $\begin{array}{l}\text { Jessie } \\
\text { Joanna }\end{array}$ & $\begin{array}{l}\text { Law } \\
\text { Nursing }\end{array}$ & $\begin{array}{c}\text { Law } \\
\text { Nursing }\end{array}$ & $\begin{array}{c}\text { Graduate } \\
\text { Undergraduate }\end{array}$ \\
\hline Jordan & Theology and Ministry & Theology/Ministry & Graduate \\
\hline Kayla & Arts and Sciences & Humanities & Undergraduate \\
\hline Kelly & Education & Education & Both \\
\hline Kristen & Arts and Sciences & Humanities & Undergraduate \\
\hline Kristina & Business & Business & Undergraduate \\
\hline Linda & Education & Counseling/Psychology & Both \\
\hline Lisa & Arts and Sciences & Humanities & Both \\
\hline
\end{tabular}




\begin{tabular}{|c|c|c|c|}
\hline $\begin{array}{c}\text { Faculty } \\
\text { Participant } \\
\text { (pseudonym) }\end{array}$ & School (pseudonym) & General Discipline & Teaching Level \\
\hline Marcus & Arts and Sciences & Humanities & Both \\
\hline Marianne & Arts and Sciences & Humanities & Undergraduate \\
\hline Matthew & Education & Education & Both \\
\hline Maxine & Arts and Sciences & Humanities & Undergraduate \\
\hline Melanie & Arts and Sciences & Humanities & Both \\
\hline Mitch & Business & Business & Undergraduate \\
\hline Rachel & Arts and Sciences & Humanities & Undergraduate \\
\hline Samuel & Law & Law & Graduate \\
\hline Silas & Arts and Sciences & Humanities & Undergraduate \\
\hline Simon & Arts and Sciences & Social Sciences & Undergraduate \\
\hline Terri & Theology and Ministry & Theology/Ministry & Graduate \\
\hline Yael & Arts and Sciences & Humanities & Both \\
\hline
\end{tabular}

\section{Note.}

Interview Participants: Faculty in the humanities $(n=11 ; 30 \%)$, social sciences $(n=3 ; 8 \%)$, and STEM fields $(n=3$; $8 \%$ ) were represented within the arts and sciences.

Survey Participants: Most survey participants identified their primary campus role as faculty members ( $n=252$; $86 \%)$, with the remainder identifying as graduate students $(n=21 ; 7 \%)$, administrators $(n=12 ; 4 \%)$, and staff $(n=7$; $2 \%)$. Roughly half identified as men $(n=135 ; 47 \%)$ or women $(n=138 ; 48 \%)$, with the rest preferring not to answer $(n=14 ; 5 \%)$. With respect to race/ethnicity, most instructors identified as White, non-Hispanic $(n=222 ; 79 \%)$. The remaining instructors identified as Asian $(n=14 ; 5 \%)$; Black or African American $(n=5,2 \%)$; Hispanic or Latinx $(n=13 ; 5 \%)$; multiracial $(n=4 ; 1 \%)$; or other race/ethnicity $(n=2 ; 1 \%)$. Seven percent $(n=21)$ preferred not to answer the question. Participants from eight schools were represented: adult and continuing education $(n=13 ; 4 \%)$, arts and sciences $(n=157 ; 54 \%)$, business $(n=33 ; 11 \%)$, education $(n=36 ; 12 \%)$, law $(n=17 ; 6 \%)$, nursing $(n=12 ; 4 \%)$, social work $(n=15 ; 5 \%)$, and theology $(n=7 ; 2 \%)$. The sample was roughly representative of the population of the university, although men were slightly under-represented. 
Table B

Excerpts from Faculty Course Evaluations: Alignment with Each Theme

\begin{tabular}{|c|c|c|c|}
\hline Theme & Subtheme & $\begin{array}{c}\text { Sub- } \\
\text { subtheme }\end{array}$ & Example Excerpts from Course Evaluations \\
\hline \multirow[t]{2}{*}{$\begin{array}{l}\text { Intentional } \\
\quad \text { and } \\
\text { purposeful } \\
\text { course design }\end{array}$} & -- & -- & $\begin{array}{l}\text { "I think [the professor] had the best transition to remote } \\
\text { learning. She modified the syllabus in order to make it a bit } \\
\text { more feasible to work out remotely, and it was clear that she put } \\
\text { a lot of thought into all of the changes. Because of that clear } \\
\text { effort, the students in the class also stepped up and tried extra } \\
\text { hard to keep everything normal." }\end{array}$ \\
\hline & -- & -- & $\begin{array}{l}\text { "Our professor did an entire new syllabus which included } \\
\text { different activities that really helped us with the stress of online } \\
\text { classes and our final grade. [This professor] was the professor } \\
\text { that helped me adapt with online classes the most." } \\
\text { "I really appreciated that you were organized and had a set plan } \\
\text { for exactly what we were doing for every class period. It made } \\
\text { it much easier to know what was coming ahead." }\end{array}$ \\
\hline $\begin{array}{l}\text { Establishing } \\
\text { clear } \\
\text { expectations }\end{array}$ & & & $\begin{array}{l}\text { "The instructor did a fantastic job handling the transition to } \\
\text { online - he was very clear about the new format and what was } \\
\text { expected of the students and gave students plenty of } \\
\text { opportunities to obtain points and help them through the } \\
\text { transition. He sent out weekly emails detailing exactly what was } \\
\text { going on, and came up with several fun, new initiatives to keep } \\
\text { students engaged." }\end{array}$ \\
\hline \multirow{6}{*}{$\begin{array}{l}\text { Fostering } \\
\text { supportive } \\
\text { and } \\
\text { trustworthy } \\
\text { classroom } \\
\text { environments }\end{array}$} & $\begin{array}{l}\text { Faculty-student } \\
\text { interactions }\end{array}$ & -- & $\begin{array}{l}\text { "[The professor] cares about her students a lot and it has been } \\
\text { made very clear during these hard times." }\end{array}$ \\
\hline & & & $\begin{array}{l}\text { "Amazing job being sensitive to students' needs, even before the } \\
\text { whole covid crisis began." }\end{array}$ \\
\hline & & & $\begin{array}{l}\text { "Thank you for being so understanding and accommodating to } \\
\text { our extenuating circumstances this semester. You were always } \\
\text { very helpful and took off a lot of the stress that we all felt } \\
\text { during this time." }\end{array}$ \\
\hline & & & $\begin{array}{l}\text { "[The professor] is a wonderful professor. She cares deeply for } \\
\text { her students, and always encourages them to do their best and to } \\
\text { make them feel comfortable with the material. She provided } \\
\text { such a welcoming classroom atmosphere." }\end{array}$ \\
\hline & & & $\begin{array}{l}\text { "I appreciated [the professor's] openness to feedback and } \\
\text { willingness to adjust and re-work the course in accordance with } \\
\text { both those suggestions and the extenuating circumstances of } \\
\text { this semester." }\end{array}$ \\
\hline & $\begin{array}{l}\text { Student-student } \\
\text { interactions }\end{array}$ & $\begin{array}{l}\text { Small } \\
\text { group } \\
\text { activities }\end{array}$ & $\begin{array}{l}\text { "We ended up doing class in small groups and it gave me a } \\
\text { better chance to share since I have a harder time in front of the } \\
\text { whole classroom. It also allowed for more in-depth } \\
\text { conversation." }\end{array}$ \\
\hline
\end{tabular}




\begin{tabular}{|c|c|c|}
\hline & $\begin{array}{l}\text { Creative } \\
\text { utilization } \\
\text { of } \\
\text { technology }\end{array}$ & $\begin{array}{l}\text { "The ability to have conversation in much smaller groups [when } \\
\text { taking class online] offered better access to conversation with } \\
\text { [the professor] than our large class sessions." } \\
\text { "[The professor] embraced the online course and technological } \\
\text { tools with great optimism. She learned how to best use the } \\
\text { technology (such as effectively using breakout rooms, taking } \\
\text { polls, and having the class post comments in the group chat)." }\end{array}$ \\
\hline & & $\begin{array}{l}\text { "[The professor] used the random breakout rooms really } \\
\text { effectively during class discussions so that I got to have } \\
\text { discussions with many more classmates than I probably would } \\
\text { have normally." }\end{array}$ \\
\hline & & $\begin{array}{l}\text { "I also thought the poll feature was really engaging and an } \\
\text { aspect that was not as common in in-person classes." }\end{array}$ \\
\hline $\begin{array}{l}\text { Incorporating } \\
\text { community } \\
\text { outside the } \\
\text { classroom }\end{array}$ & -- & Not mentioned in the course evaluations \\
\hline
\end{tabular}

\section{Interview Questions}

\section{Part I. Introduction:}

1. Before turning to your experience teaching online, could you tell me a bit about your general teaching experience?

a. Probe: How long have you been teaching at [CURRENT INSTITUTION]?

b. Probe: Did you previously teach at other institutions? If so, where?

c. Probe: What course formats do you typically teach (e.g., small seminar, large lecture)?

d. Probe: Do you typically teach undergraduate- and/or graduate-level courses?

e. Probe: Do you typically teach introductory and/or advanced courses?

2. What courses did you teach in the Spring? And could you briefly describe each course?

a. Probe: What was the format of each class prior to transitioning online (e.g., small seminar, large lecture)?

b. Probe: What academic level were the students in your courses (e.g., undergrad vs. graduate; introductory vs. advanced undergraduate course; mixed level)?

c. Probe: How many students were enrolled in each of your courses?

3. And as I mentioned earlier, for our research, we're not only interested in formative education, but formative education in an online environment, so can you also tell me a little bit about your experience teaching online? Had you taught an online or remote course prior to this spring semester?

a. Follow-up--If yes: Had you previously taught the spring 2020 courses online?

b. Follow-up--If yes: About how many courses have you taught online?

c. Follow-up--If yes: How did your experience teaching online this time differ from previous semesters, if at all? 
4. How would you describe your initial reaction to learning that you would need to adjust your course to an online/remote format?

a. Probe: Did you have any preconceived notions about online teaching and learning?

b. Probe: How, if at all, have your attitudes toward online teaching and learning changed as a result of your experience this spring semester?

\section{Part II. Practices Targeting Formative Education:}

\section{A. Formative Education - General Understanding}

1. When you hear 'formative education' or 'whole-person education,' what is your interpretation of the concept? What are some words or phrases you would use to describe this educational approach?

a. Probe: How would you describe the role of formative education in your particular academic discipline?

2. When considering the courses you have taught at [CURRENT INSTITUTION], prior to the pandemic, could you please tell me about one or two in which successful formative education occurred?

a. Which courses fostered student formation and development of the whole student?

b. Follow up: Could you briefly describe the course?

c. Follow up: Which aspects of the course accomplished formative education?

d. Follow up: Could you describe a few examples of student formation that occurred within this course?

\section{B. Formative Education Online}

\section{Formative Education Online - Multiple Dimensions}

1. When you were teaching online this Spring, were there teaching practices or strategies you used to foster students' development beyond the subject matter, like their emotional, social, ethical, or spiritual development?

a. If so, which of these dimensions did you focus on? Why did you choose these dimensions?

b. Could you give a few examples of the techniques that you tried and the results?

2. Were there any teaching practices or strategies you used to help students forge connections between these multiple dimensions? [THIS MIGHT BE AN OPTIONAL QUESTION, ONE TO ASK TOWARD THE END]

a. Or: were there any teaching practices or strategies you used to help students integrate multiple dimensions of their development?

b. Could you give a few examples of the techniques you tried and the student response?

Formative Education Online - A Sense of Purpose

1. What does it mean to you for a student to have a "sense of purpose"? 
a. Probe: can you give some examples of when a student has developed a sense of purpose in their lives?

2. In your online course this Spring, were there teaching practices or strategies you used to try to foster students' sense of purpose (or engage them in reflection about their sense of purpose)?

a. If so, what were the results of your teaching practices? How did students respond to your efforts?

\section{Formative Education Online - A Sense of Community}

1. Were there teaching practices or strategies you used to try to foster students' sense of community (either within the class community or within a broader community)?

a. If so, what were the results of your teaching practices? How did students respond to your efforts?

2. Did you use the community of the class to foster students' own individual development? If so, how?

3. As you know, many international students returned to their home countries due to the pandemic, which might have made them feel more detached from campus than their domestic peers. Did you feel you were able to foster a sense of community among international students?

a. Probe: If any, what strategies did you use?

b. Probe: How did you know?

\section{Concluding questions}

1. Did you develop any new activities, assignments, or assessments for teaching formative education in an online environment? We are particularly interested in activities, assignments, or assessments that you are especially proud of.

a. Follow-up: Why did you select this particular activity/assignment/assessment?

What made this activity/assignment/assessment successful?

b. Are there any materials from your course that you believe would further demonstrate your approach to formative education online? An example might be an assignment or class activity. We would welcome any other artifacts you would be willing to share.

c. Probe: How do you know that successful student formation has occurred?

i. Or -- How do you measure successful student formation?

2. How, if at all, did the online environment influence your teaching and ability to engage students in formative education?

a. Or -- What were the affordances and constraints of the online learning environment for facilitating formative education?

b. Probe: Was there a particular aspect of formative education that was particularly challenging or rewarding to facilitate online?

c. Probe: How would you compare your experiences teaching formative education online and in-person settings?

d. Probe: Has your understanding of formative education changed as a result of your online teaching experience? 
i. Follow up-- If so, how?

ii. Follow up-- If not, why?

3. Looking toward Fall 2020 , what advice or strategies would you give a faculty member seeking to facilitate formative education in their online course?

a. Or-- if you were to teach this course again, is there anything you would do differently?

b. Or-- Suppose you were looking to hire a new faculty member to teach an online course this coming fall. What qualities would you look for in a potential hire?

i. Follow-up: Are these characteristics different from what you would look for in a traditional in-person class?

Supplemental Questions:

4. Now that the course is complete, were there any teaching practices or strategies you used to encourage student formation beyond the duration of your course (or to encourage student formation as an ongoing process)?

a. If so, what techniques did you use? How did students respond to your efforts?

\section{Part III. Conclusion:}

1. Is there anything else you would like to share about your experience teaching online this past spring and/or your thoughts moving forward, especially as it pertains to formative education? 


\section{Survey Questions}

The current paper is part of a larger study. Below are the survey questions relevant to this paper.

Prior to spring 2020, had you ever taught a completely online course?

\begin{tabular}{ccc}
\hline Yes & No & Total Respondents \\
\hline $54(16 \%)$ & $288(84 \%)$ & $342(100 \%)$ \\
\hline
\end{tabular}

When teaching online, how often do you do the following activities?

\begin{tabular}{|c|c|c|c|c|c|c|}
\hline & Never & Rarely & Sometimes & Often & $\begin{array}{l}\text { Very } \\
\text { Often }\end{array}$ & $\begin{array}{c}\text { Total } \\
\text { Respondents }\end{array}$ \\
\hline $\begin{array}{l}\text { I offer students opportunities to share } \\
\text { how they are doing. }\end{array}$ & $\begin{array}{c}4 \\
(1 \%)\end{array}$ & $\begin{array}{c}24 \\
(7 \%)\end{array}$ & $\begin{array}{c}91 \\
(27 \%)\end{array}$ & $\begin{array}{c}106 \\
(32 \%)\end{array}$ & $\begin{array}{c}108 \\
(32 \%)\end{array}$ & $\begin{array}{c}333 \\
(100 \%)\end{array}$ \\
\hline $\begin{array}{l}\text { I contact students who fall behind in } \\
\text { class to offer support. }\end{array}$ & $\begin{array}{c}0 \\
(0 \%)\end{array}$ & $\begin{array}{c}8 \\
(3 \%)\end{array}$ & $\begin{array}{c}68 \\
(21 \%)\end{array}$ & $\begin{array}{c}108 \\
(34 \%)\end{array}$ & $\begin{array}{c}136 \\
(43 \%)\end{array}$ & $\begin{array}{c}320 \\
(100 \%)\end{array}$ \\
\hline $\begin{array}{l}\text { I modify my course to accommodate } \\
\text { students' feedback about what is } \\
\text { working well in the course and what } \\
\text { could use improvement. }\end{array}$ & $\begin{array}{c}2 \\
(1 \%)\end{array}$ & $\begin{array}{c}9 \\
(3 \%)\end{array}$ & $\begin{array}{c}60 \\
(19 \%)\end{array}$ & $\begin{array}{c}134 \\
(42 \%)\end{array}$ & $\begin{array}{c}113 \\
(36 \%)\end{array}$ & $\begin{array}{c}318 \\
(100 \%)\end{array}$ \\
\hline $\begin{array}{l}\text { I modify my course to accommodate } \\
\text { my students' needs. }\end{array}$ & $\begin{array}{c}3 \\
(1 \%)\end{array}$ & $\begin{array}{c}7 \\
(2 \%)\end{array}$ & $\begin{array}{c}63 \\
(21 \%)\end{array}$ & $\begin{array}{c}122 \\
(41 \%)\end{array}$ & $\begin{array}{c}106 \\
(35 \%)\end{array}$ & $\begin{array}{c}301 \\
(100 \%)\end{array}$ \\
\hline $\begin{array}{l}\text { I create opportunities for students to } \\
\text { work in pairs or smaller groups that } \\
\text { allow collaborations and more } \\
\text { personal connections. }\end{array}$ & $\begin{array}{c}16 \\
(5 \%)\end{array}$ & $\begin{array}{c}26 \\
(9 \%)\end{array}$ & $\begin{array}{c}58 \\
(19 \%)\end{array}$ & $\begin{array}{c}61 \\
(20 \%)\end{array}$ & $\begin{array}{c}143 \\
(47 \%)\end{array}$ & $\begin{array}{c}304 \\
(100 \%)\end{array}$ \\
\hline $\begin{array}{l}\text { I provide students opportunities to get } \\
\text { to know their classmates. }\end{array}$ & $\begin{array}{c}3 \\
(1 \%)\end{array}$ & $\begin{array}{c}12 \\
(4 \%)\end{array}$ & $\begin{array}{c}76 \\
(25 \%)\end{array}$ & $\begin{array}{c}100 \\
(33 \%)\end{array}$ & $\begin{array}{c}111 \\
(37 \%)\end{array}$ & $\begin{array}{c}302 \\
(100 \%)\end{array}$ \\
\hline I make sure each student feels valued. & $\begin{array}{c}0 \\
(0 \%) \\
\end{array}$ & $\begin{array}{c}0 \\
(0 \%) \\
\end{array}$ & $\begin{array}{c}22 \\
(7 \%)\end{array}$ & $\begin{array}{c}103 \\
(34 \%)\end{array}$ & $\begin{array}{c}177 \\
(59 \%)\end{array}$ & $\begin{array}{c}302 \\
(100 \%) \\
\end{array}$ \\
\hline $\begin{array}{l}\text { I strive to create a sense of } \\
\text { community in the classroom. }\end{array}$ & $\begin{array}{c}0 \\
(0 \%) \\
\end{array}$ & $\begin{array}{c}3 \\
(1 \%)\end{array}$ & $\begin{array}{c}32 \\
(11 \%)\end{array}$ & $\begin{array}{c}92 \\
(31 \%) \\
\end{array}$ & $\begin{array}{c}174 \\
(58 \%) \\
\end{array}$ & $\begin{array}{c}301 \\
(100 \%)\end{array}$ \\
\hline $\begin{array}{l}\text { I am accessible to my students } \\
\text { through a variety of means (drop-in, } \\
\text { office hours, email, before or after } \\
\text { class). }\end{array}$ & $\begin{array}{c}0 \\
(0 \%)\end{array}$ & $\begin{array}{c}1 \\
(<.5 \%)\end{array}$ & $\begin{array}{c}12 \\
(4 \%)\end{array}$ & $\begin{array}{c}81 \\
(27 \%)\end{array}$ & $\begin{array}{c}206 \\
(69 \%)\end{array}$ & $\begin{array}{c}300 \\
(100 \%)\end{array}$ \\
\hline
\end{tabular}

How have you utilized Zoom (or other video conferencing tools) in your classes? Check all that apply. I am currently doing this practice [during the COVID-19 pandemic]:

Held live lectures

Held live discussion sessions

Invited guest lecturers

Had students give presentations to the entire class

Met with one student individually

Met with a small group of students

Used the polling tool, chat box, or other tool to

increase participation

Used small group breakout rooms in class
Checked

$239(82 \%)$

$236(81 \%)$

$135(46 \%)$

$172(59 \%)$

$270(92 \%)$

$193(66 \%)$

$179(61 \%)$

$205(70 \%)$

Not Checked
$53(18 \%)$
$56(19 \%)$
$157(54 \%)$
$120(41 \%)$
$22(8 \%)$
$99(34 \%)$
$113(39 \%)$
$87(30 \%)$

Total Respondents

$292(100 \%)$

292 (100\%)

$292(100 \%)$

$292(100 \%)$

292 (100\%)

$292(100 \%)$

$292(100 \%)$

$292(100 \%)$ 